Тетяна ВЕРЕТЕНКО, orcid.org/0000-0002-7184-3764 кандидат педагогічних наук, професор, професор кафедри соиіальної педагогіки та соціальної роботи Київького університету імені Бориса Грінченка

(Київ, Україна) t.veretenko@kubg.edu.ua

\author{
Яна КЛИМЧУК, \\ orcid.org/0000-0003-0289-5373 \\ магістрантка Інституту людини \\ Київського університету імені Бориса Грінченка \\ (Київ, Україна) ymyankova.il19@kubg.edu.ua
}

\title{
ТЕХНОЛОГІЇ СОЦІАЛЬНОЇ РОБОТИ ІЗ ЖІНКАМИ, ЯКІ ПОСТРАЖДАЛИ ВІД ДОМАШНЬОГО НАСИЛЬСТВА
}

\begin{abstract}
У статті розкрито актуальну проблему домашнього насильства стосовно жінок, наведено ицири, які чітко характеризують ступінь складності ситуаиії із цією темою в Україні. Шляхом наведення статистичних даних i відомостей із відповідних державних структур доведено необхідність використання змістово-технологічного забезпечення соціальної роботи з постраждалими від домашнього насильства. Для чіткого опису проблеми проведено мінідослідження у вигляді анкетування. Також проаналізовано низку робіт науковиів, які досліджують тему домашнього насилля та боротьби з ним. Визначено шляхи підвищення ефективності змістово-технологічного забезпечення сочіальної роботи в роботі із жінками, які постраждали від домамнього насильства. За допомогою моніторингу іноземних інформаційних і наукових ресурсів, сайтів державних органів і дослідницьких центрів проаналізовано відмінність у роботі украӥнських соціальних і спеціалізованих иентрів і дотичних структур інших країн. Установлено різні типи роботи з постраждалими жінками та посадові обов'язки співробітників соціальних і спеціалізованих цеентрів допомоги. Виокремлено конкретні способи спілкування із жертвами домашнього насилля та важливі складники роботи з постраждалими жінками. Крім того, ідеться про наслідки роботи спеціалістів із жінками, які пережили домашне насильство. Визначено шляхи подолання депресивних станів у працівників цุентрів допомоги. Важливою частиною статті є перелік, визначений для вдосконалення вмінь і навиків соиіальних працівників. Після дослідження досвіду зарубіжних структур, пов 'язаних із боротьбою з домашнім насиллям, вивчення досліджень, які описують помилкові шляхи спеціалізованих иеентрів, установлено, чого потребують відповідні структури на території Украӥни.
\end{abstract}

Ключові слова: насилля, жінки, сочіальна робота, домашнє насилля, жертва, фахівиі, психічне здоров'я.

Tetiana VERETENKO, orcid.org/0000-0002-7184-3764 Candidate of Pedagogical Sciences, Professor, Professor at the Department of Social Pedagogy and Social Work Borys Grinchenko Kyiv University (Kyiv,Ukraine)t.veretenko@kubg.edu.ua

\author{
Yana KLYMCHUK, \\ orcid.org/0000-0003-0289-5373 \\ Master's Degree at the Institute of Human Sciences \\ Borys Grinchenko Kyiv University \\ (Kyiv, Ukraine) ymyankova.il19@kubg.edu.ua
}

\section{TECHNOLOGIES OF SOCIAL WORK WITH WOMEN VICTIMS OF DOMESTIC VIOLENCE}

The article reveals the current problem of domestic violence against women, provides figures that clearly characterize the complexity of the situation on this topic in Ukraine. By providing statistics and information from relevant government agencies, the need to use the content and technological support of social work with victims of domestic violence has been proven. To clearly describe the problem, a mini-survey was conducted in the form of a questionnaire. This material also 
analyzes a number of works by scientists who study the topic of domestic violence and combating it. Ways to increase the effectiveness of content and technological support of social work in working with women victims of domestic violence have been identified. Also, with the help of monitoring of foreign information and scientific resources, websites of state bodies and research centers, the difference in the work of Ukrainian social and specialized centers and related structures of other countries was analyzed. Different types of work with affected women and job responsibilities of employees of social and specialized care centers have been established. Specific ways of communicating with victims of domestic violence and important components of working with affected women are highlighted. In addition, this article discusses the implications of working with women who have experienced domestic violence. Ways to overcome depression in the staff of care centers have been identified. An important part of this article is the list set out to improve the skills of social workers. After studying the experience of foreign structures related to the fight against domestic violence, studying studies that describe the erroneous ways of specialized centers, it was established what the relevant structures in Ukraine need.

Key words: violence, women, social work, domestic violence, victim, specialists, mental health.

Постановка проблеми. Домашнє насильство стосовно жінок є комплексним явищем, яке містить низку чинників соціального, психологічного та економічного характеру. Це діяння має широкий спектр негативних фізичних, психологічних i соціальних наслідків для всієї родини: як для жертви, усієї родини, так і для кривдника.

У період 2016-2017 років українське законодавство зазнало змін щодо врегулювання питання боротьби 3 домашнім насиллям, визначено нормативно-правову базу соціальної роботи із жінками, що постраждали від домашнього насильства. Такі зміни мали б поетапно зменшувати кількість постраждалих від домашнього насильства, однак статистичні дані Міністерства соціальної політики України щодо кількості осіб, які постраждали від різних форм домашнього насильства, свідчать про інше. За інформацією відомства, станом на 2018 р. жертвами домашнього насильства в Україні стали 1,8 млн. осіб, що становить 4,2\% від загальної кількості населення України. Кількість жертв домашнього насильства, що загинули від фізичних травм, сягнула 600 осіб. Такі цифри дають підставу зробити висновок, що ефективність уже наявної нормативно-правової бази не є достатньою, особливо в умовах швидкого реагування на потребу. Найтрагічнішим є те, що 60\% жінок, які страждають від домашнього насильства, не визнають цього та не звертаються до державних установ за допомогою.

Аналіз досліджень. Проблема домашнього насильства стосовно жінок представлена в нечисленних роботах науковців різних галузей наук. Знавці юридичних наук Т. Малиновська, О. Дніпров розкривають проблему шляхом дослідження Закону України «Про запобігання та протидію домашньому насильства» і Кримінального кодексу України з метою допомоги постраждалим реалізувати свої права, уживають заходи із протидії та запобігання домашньому насильству (Малиновська, 2016). 3 юридичного погляду цю тему вдається дослідити найглибше, оскільки насилля порушує права та гідність людини, а також учиняє шкоду здоров'ю. Зокрема, К. Гурковська дослідила шляхи вдосконалення нормативно-правового забезпечення попередження насилля в сім’ї (Гурковська, 2014), а М. Заславська вивчає питання кримінального правового захисту жінок від домашнього насильства. Водночас А. Вознюк вивчає соціологічні аспекти домашнього насильства. Особливостям надання медичної допомоги посвячені роботи Л. Хіміон, I. Климась, які оприлюднили низку рекомендацій і порад щодо виявлення, оцінювання та ведення жертви домашнього насилля в практиці сімейного лікаря (Хіміон, 2013).

3 психологічного погляду цю проблему досліджували С. Сахно й Т. Малиновська. Науковці визначили поняття насилля в сім’і, чинники, що провокують це явище, i шляхи профілактики насилля стосовно жінок, запропонували низку заходів щодо запобігання неправомірним діям стосовно жінок у сім'ях (Сахно, 2018).

Соціально-педагогічні аспекти проблеми домашнього насильства стосовно жінок досліджують науковці: Т. Журавель, Я. Бордіян, О. Кулаковська, О. Лясковська, Г. Остапчук, Т. Марценюк, О. Дудоров, М. Хавронюк та інші. У роботах дослідників запропоновано різні інноваційні ідеї щодо викорінення, профілактики цієї проблеми, психічної корекції та реабілітації жертв домашнього насилля.

Детальне дослідження проблеми домашнього насилля стосовно жінок потребує:

- визначення та характеристики особливостей змістово-технологічного забезпечення соціальної роботи із жінками, які постраждали від домашнього насильства, у роботі фахівців соціальних i спеціалізованих центрів;

- розкриття актуальності соціальної проблеми домашнього насильства стосовно жінок у сучасних умовах;

- аналізу зарубіжного досвіду змістово-технологічного забезпечення соціальної роботи iз жінками, які постраждали від домашнього насильства. 
Світова кількість жертв пограбувань, авто- та авіакатастроф, стихійних лих $є$ значно меншою, ніж кількість жінок, постраждалих від домашнього насилля. Постраждалі жінки намагаються вчинити самогубство в п'ять разів частіше, ніж жінки, які не знають насилля. Жінки, яких били, періодично впадають у тривалі депресії й удаються до частого вживання алкоголю та наркотиків. Таким особам украй необхідна психологічна допомога, однак вони рідко самостійно звертаються до спеціалістів.

Згідно із Законом України «Про запобігання та протидію домашньому насильству», домашне насильство - неправомірні фізичні, сексуальні, психологічні або економічні діяння, що вчиняються в сім'ї, а також погрози вчинення таких діянь. Насилля в сім'ї охоплює всі соціальні, релігійні, класові, культурні й соціоекономічні групи (Закон України: 2019). Варто пояснити, що економічне насилля передбачає навмисне позбавлення житла, їжі, одягу, іншого майна, коштів або документів, можливості користуватися ними, залишення без догляду або турботи, перешкоджання в отриманні необхідних послуг 3 лікування або реабілітації, заборону працювати, примус до праці, заборону вчитися й інші правопорушення економічного характеру. Психологічне насильство - словесні образи, погрози, у тому числі щодо третіх осіб, приниження, переслідування, залякування, інші діяння, спрямовані на обмеження волевиявлення особи, контроль у репродуктивній сфері. Сексуальне насилля передбачає будь-які дії сексуального характеру, учинені щодо повнолітньої особи без згоди або щодо дитини незалежно від ії згоди або в присутності дитини, примушення до акту сексуального характеру з третьою особою, а також інші правопорушення проти статевої свободи чи статевої недоторканності, зокрема вчинені щодо дитини або в ії присутності. Фізичним насильством уважають ляпаси, стусани, штовхання, щипання, шмагання, кусання, а також незаконне позбавлення волі, нанесення побоїв, катування, заподіяння тілесних ушкоджень різного ступеня тяжкості, залишення в небезпеці, ненадання допомоги особі, яка перебуває в небезпечному для життя стані, заподіяння смерті, учинення інших правопорушень насильницького характеру (Проект Закону України, 2017).

Боротися 3 наслідками кожного виду насильства й працювати над способами запобігання насиллю - обов'язок співробітників соціальних і спеціалізованих центрів. У процесі виконання своїх посадових обов'язків спеціалісти керуються відповідними правилами й застосовують різні тех- нології як особливий вид професійної діяльності фахівця соціальної роботи, який містить методи, форми, прийоми та впливи, що спрямовуються на вирішення актуальних соціальних проблем.

Метою статті $\epsilon$ визначення змістово-технологічне забезпечення соціальної роботи із жінками, які постраждали від домашнього насильства в соціальних і спеціалізованих центрах.

Виклад основного матеріалу. Реалізувати мету статті вдалося шляхом використання емпіричних методів дослідження, зокрема анкетування. Ми опитали 17 фахівців соціальної роботи соціальних i спеціалізованих центрів міста Києва, які мають досвід роботи із жінками, котрі постраждали від домашнього насильства. Опитування показало, що впродовж 2019 р. найменшою кількістю жінок, які звернулися до спеціалістів одного із центрів Києва, було 15 осіб. Водночас найбільшою кількістю жінок, які звернулися по допомогу, стали 165 осіб. 81,3\% опитаних фахівців соціальної роботи пов'язують це з прийняттям Закону України «Про запобігання та протидію домашнього насильства» від 07.12.2017: жінки почали усвідомлено ставитися до проблеми, 3 якою зіштовхнулися, проінформовані, куди звертатися по допомогу та як діяти в такій ситуації. При цьому статистика Міністерства соціальної політики показує, що $60 \%$ жінок усе ж мовчать і не звертаються по допомогу.

Анкетування 35 жінок віком від 18 років показало, що найчастіше жінки, які звертаються по допомогу до центрів соціальних і спеціалізованих служб, страждають від психологічних і фізичних форм домашнього насильства.

Здебільшого фахівці соціальної роботи із жінками, які постраждали від домашнього насильства, здійснюють соціальну роботу, що передбачає вивчення ситуації, надання соціальних послуг, надання інформації та мотивування клієнтки до отримання подальшої допомоги, ведення випадку, консультування клієнтки, влаштування до соціальної квартири, якщо ситуація потребує того, перенаправлення. Найменша кількість відповідей пов'язана 3 наданням гуманітарної та соціальноекономічної допомоги, надання юридичних консультацій. Тільки в одній відповіді зазначено про необхідність надання психологічної допомоги.

Анкетування працівників центрів соціальних і спеціалізованих служб дало нам змогу з'ясувати, які технології соціальної роботи фахівці застосовують у роботі. Отже, близько $80 \%$ фахівців соціальної роботи вдаються до екстреного (кризового) втручання; консультування (психологічного, юридичного, інформаційного); перенаправлення до 
спеціалізованих закладів; представництва інтересів (сприяння в оформленні документів, працевлаштування тощо); соціального супроводу; профілактичних робіт; індивідуальних і групових робіт; надання інформації та мотивування.

Також важливими складниками роботи 3 постраждалими жінками $є$ соціальна корекція; соціальна терапія; арт-терапія; соціально-психологічна адаптація. Ці технології найбільший вплив мають на жінок, які страждали від психологічного та фізичного домашнього насильства.

У дослідженні важливо визначити, які програми застосовують фахівці центрів соціальних і спеціалізованих служб. Ми дізналися, що 50\% спеціалістів використовують Корекційну програму для жінок та дівчат, які постраждали від насильства, розроблену МБФ «Українська фундація громадського здоров'я» та затверджену Міністерством соціальної політики. Ця програма $\epsilon$ комплексною, містить тренінгові заняття, індивідуальну та групову роботу із жертвами, спрямована на реабілітацію всіх сфер особистості жінок, які постраждали від домашнього насильства.

На теренах інших країн соціальну роботу як професію аналізують із різних точок зору. Єдиного визначення соціальної роботи, яке було б визнане всіма країнами, не існує. Попри це, діяльність соціальних працівників спрямована на вироблення цілісного, гармонізованого стандарту практики соціальної роботи. Тому, звертаючись до теорії поведінки людини та соціальних систем, можемо констатувати, що соціальна робота передбачається саме там, де існує взаємодія між людьми та їхнім середовищем.

Ми проаналізували досвід інших країн і визначили, що в різних державах допомогу щодо підвищення кваліфікації соціальних працівників у роботі $з$ постраждалими від домашнього насильства надають різні агенції. Зокрема, у Великобританії соціальні працівники підзвітні Генеральній раді соціального обслуговування, яка дає працівникам можливість влаштуватися на роботу, здобути додаткову освіту й періодично проходити додаткове навчання. Для цього створено пілотну програму «Новокваліфікований соціальний працівник», яка надає інтенсивну підтримку й навчання соціальним працівникам. Водночас у Сполучених Штатах Америки співробітники всіх центрів соціальної роботи зобов'язані підвищувати свою кваліфікацію, цей процес навчання жорстко контролюється. У Польщі соціальні працівники вимушені постійно вдосконалювати свої не тільки професійні, а й особистісні якості. Це потрібно для того, аби клієнт - людина, яка потре- бує допомоги, міг швидше відкритися й довіритися. Отже, соціальним працівникам важливіше піклуватися про добробут постраждалих, задовольняти їхні життєві, психологічні, соціальні потреби (Mayo Clinic Staff, 2020).

Отже, соціальні працівники повинні:

1. Надавати психологічну підтримку, яка полягає в тому, щоб працівник переконав постраждалу, що ії почуття й особисті справи важливі; допоміг підвищити самооцінку жертви; допоміг постраждалій зрозуміти, що вона все робить правильно; підтримав жінку під час проходження юридичних процедур; допоміг зрозуміти, що жертва не відповідальна за насилля; заохотив вільно висловлюватися; переконав, що постраждалій допоможуть.

2. Інформувати суспільство про способи виявлення насилля; наслідки перебування під насильним тиском; необхідність знань про особисті й громадянські права; міфи і стереотипи щодо ролей окремих членів сім'ї та їх впливу на функціонування сім'ї; важливість обізнаності в правових аспектах домашнього насилля; способи отримання допомоги від установ, які допомагають жертвам насилля.

3. Мотивувати й надавати суспільству доступ до різних форм допомоги шляхом показу реальних можливостей виходу із ситуацій, пов'язаних із насиллям; заохочення прийняти самостійне рішення й уживання відповідних заходів щодо подолання насилля в сім'ї; заохочення вдаватися до інших форм допомоги: психотерапії, правової допомоги.

4. Розвивати здібності й навички, корисні для боротьби з насиллям, створюючи покрокові плани безпеки; аналізуючи окремі фактори розвитку конфліктів і фактори полегшення звільнення жертви від впливу винного; розвиваючи в суспільства навики, необхідні в процесі боротьби з насиллям: виклик поліції, збирання доказів, написання заяв тощо (Stanek, 2014).

Крім того, робота соціальних працівників полягає в задоволенні соціальних і побутових потреб людей, які переживають кризу через насилля; наданні притулку й невідкладної допомоги постраждалим.

Серед обов'язків соціальних працівників наявне й інституційне втручання, яке трактується як реакція на сигнали про домашнє насилля. Тобто соціальні працівники мають діагностувати сімейні ситуації; установлювати контакт із потерпілими й інформувати їх про права та можливості в отриманні допомоги (Danis, 2003).

Висновки. Проведене дослідження та аналіз отриманих результатів дали змогу дійти висновку, 
що технології соціальної роботи, які застосовують у роботі фахівці соціальної роботи із жінками, які постраждали від домашнього насильства, не $\epsilon$ повноцінним інструментом, який зможе запобігти повторним випадкам домашнього насильства. Спеціалісти не вирішують психологічних, юридичних, медичних і педагогічних проблем постраждалих, а звертають увагу лише на соціальні проблеми.

Змістово-технологічне забезпечення соціальної роботи в соціальних і спеціалізованих службах не $\epsilon$ повноцінним. Більшість фахівців використовують у роботі тільки одну програму. Тому важливим рушієм забезпечення постраждалих допомогою $є$ розширення технологій соціальної роботи, створення інновацій, які зможуть запобігти повторним випадкам домашнього насильства стосовно жінок.

3 огляду на психологічне навантаження, соціальним працівникам також варто надати допомогу, аби вони могли поділитися труднощами й отримати інструкції щодо подальших дій. Водночас вони повинні весь час отримувати користь від удосконалення власних компетенцій у роботі із жертвами. У зв'язку з появою нових форм насильства соціальні працівники мають дізнатися про них, а також навчитися видозмінювати та вдосконалювати наявні методи і стратегії дій. I в інших державах таку допомогу соціальним працівникам надають, адже від неї залежить увесь процес надання допомоги суспільству.

Досвід інших країн, зокрема Великобританії, показує, що, чим більшою є робота держави над усуненням проблеми насилля, тим більшою $\epsilon$ результативність у плані співпраці із суспільством. Наприклад, завдяки так званому «Закону Клер» будь-яка жінка може перевірити, чи пов'язаний іiі партнер із насиллям, або за перших проявів посилів партнера до насилля може звернутися до відповідних органів і самостійно завчасно запобігти неправомірним діям щодо себе чи своїх близьких.

Отже, окрім роботи над удосконаленням надання допомоги жертвам, соціальні працівники повинні переймати досвід інших держав. Крім того, виконавча влада має надавати спеціалістам можливість співпраці з іноземними колегами, що дасть змогу обмінятися вміннями й так вплинути на статистику домашнього насилля.

\section{СПИСОК ВИКОРИСТАНИХ ДЖЕРЕЛ}

1. Гурковська К. А. Особливості здійснення спеціальних заходів із попередження насильства у сім'ї. Науковий вісник Львівського держсвного університету внутрішніх справ. 2014. № 2. С. 82-90.

2. Конвенція Ради Європи про запобігання насильству стосовно жінок і домашньому насильству та боротьбу 3 цими явищами (Стамбульська Конвенція) : доповідь для членів парламенту. Київ : К.І.С., 2013. 104 с.

3. Малиновська Т. М. Попередження насильства над жінками в сім'ї. Право і безпека. 2016. № 1 (60). С. 117-120.

4. Марценюк Т. Соціологічні дослідження домашнього насильства: методологічні засади. Збирання даних $y$ сфері насильства щодо жінок та домашнього насильства: назустріч вимогам Стамбульської Конвенції : матеріали Міжнар. конф., м. Київ, 3-4 вересня 2015 р. Київ, 2015. С. 1-11.

5. Про запобігання та протидію домашньому насильству : Закон України від 17.01.2019 № 2671-VIII. URL: https://zakon.rada.gov.ua/laws/show/2229-19\#Text (дата звернення: 02.08.2020).

6. Про запобігання та протидію домашньому насильству : Проект Закону України від 03.10.2017 № 2149-VIII. URL: http://w1.c1.rada.gov.ua/pls/zweb2/webproc4_1?pf3511=60306 (дата звернення: 04.08.2020).

7. Сахно С. В., Брагінець В. Насильство над жінками в сім'ї. Вісник Приазовського державного технічного університету. Серія «Соиіально-гуманітарні науки та публічне адміністрування». Маріуполь, 2018. Вип. 1. С. 187-190.

8. Хіміон Л. В., Климась І. В. Скринінгові методи виявлення насильства в сім’ї у практиці сімейного лікаря. Семейная медицина. 2013. № 4 (48). С. 106-109.

9. Fran S. Danis (2003) Social Work Response to Domestic Violence: Encouraging News From a New Look. AFFILIA. Vol. 18. № 2. P. 177-191.

10. Katarzyna Stanek. Praca socjalna z osoba lub rodzina z problemem przemocy. Warszawa : Centrum Rozwoju Zasobów Ludzkich, 2014. 201 p.

11. Kristin Heffernan, Jennifer Fritz, Barbara Walters, Betty Blythe. How Do Social Workers Understand and Respond to Domestic Violence? Research that Promotes Sustainability and (re)Builds Strengths. 2009. Vol. 57 (6). P. 698-713.

12. Mayo Clinic Staff. Domestic violence against women: Recognize patterns, seek help. 2020. URL: https://www.mayoclinic.org/healthy-lifestyle/adult-health/in-depth/domestic-violence/art-20048397 (accessed: 08.08.2020).

\section{REFERENCES}

1. Hurkovska K. A. (2014) Osoblyvosti zdiisnennia spetsialnykh zakhodiv iz poperedzhennia nasylstva u simi [Features of special measures to prevent domestic violence]. Scientific Bulletin of Lviv State University of Internal Affairs, no. 2, pp. $82-90$ [in Ukrainian].

2. Konventsiia Rady Yevropy pro zapobihannia nasylstvu stosovno zhinok i domashnomu nasylstvu ta borotbu z tsymy yavyshchamy (Stambulska Konventsiia): dov. dlia chleniv parlamentu [Council of Europe Convention on Preventing and Combating Violence against Women and Domestic Violence (Istanbul Convention): ext. for members of parliament]. Kyiv: K.I.S. 
3. Malynovska T. M. (2016) Poperedzhennia nasylstva nad zhinkamy v simi [Preventing violence against women in the family]. Law and security, no. 1 (60), pp. 117-120 [in Ukrainian].

4. Martseniuk T. (2015) Sotsiolohichni doslidzhennia domashnoho nasylstva: metodolohichni zasady [Sociological research of domestic violence: methodological principles]. Zbyrannia danykh u sferi nasylstva shchodo zhinok ta domashnoho nasylstva: nazustrich vymoham Stambulskoi Konventsii (Ukraine, Kyiv, September 3-4, 2015), Kyiv: Proceedings of the Data collection on violence against women and domestic violence, pp. 1-11 [in Ukrainian].

5. Verkhovna Rada Ukrainy (2019) Pro zapobihannia ta protydiiu domashnomu nasylstvu: Zakon Ukrainy vid 17.01.19 № 2671-VIII [On Prevention and Counteraction to Domestic Violence: Law of Ukraine of January 17, 2019 no. 2671 -VIII]. Available at: https://zakon.rada.gov.ua/laws/show/2229-19\#Text [in Ukrainian].

6. Verkhovna Rada Ukrainy (2017) Pro zapobihannia ta protydiiu domashnomu nasylstvu: Proekt Zakonu Ukrainy vid 03.10.2017 № 2149-VIII [On Prevention and Counteraction to Domestic Violence: Draft Law of Ukraine of October 3, 2017 no. 2149-VIII]. Available at: http://w1.c1.rada.gov.ua/pls/zweb2/webproc4_1?pf3511=60306 [in Ukrainian].

7. Brahinets V., Sakhno S. V. (2018) Nasylstvo nad zhinkamy v simi [Domestic violence against women]. Bulletin of the Azov State Technical University, vol. 1, pp. 187-190 [in Ukrainian].

8. Khimion L. V., Klymas I. V. (2013) Skryninhovi metody vyiavlennia nasylstva v simi u praktytsi simeinoho likaria [Screening methods for detecting domestic violence in the practice of a family doctor]. Family medicine, vol. 4, no. 48, pp. 106-109 [in Ukrainian].

9. Fran S. Danis (2003) Social Work Response to Domestic Violence: Encouraging News From a New Look. AFFILIA, vol. 18 , no. 2 , pp. $177-191$.

10. Katarzyna Stanek (2014) Praca socjalna z osoba lub rodzina z problemem przemocy. Warszawa: Centrum Rozwoju Zasobów Ludzkich [in Polish].

11. Barbara Walters, Betty Blythe, Jennifer Fritz, Kristin Heffernan (2009) How Do Social Workers Understand and Respond to Domestic Violence? Research that Promotes Sustainability and (re)Builds Strengths, vol. 57, no. 6, pp. 698-713.

12. Mayo Clinic Staff. Domestic violence against women: Recognize patterns, seek help. 2020. Available at: https://www.mayoclinic.org/healthy-lifestyle/adult-health/in-depth/domestic-violence/art-20048397. 